\title{
Morphology of the Stomach of Tayra (Eira barbara)
}

\author{
André Luis de Sousa Nogueira Lima', Thamara Cozzi Gonçalves', Érika Renata Branco ${ }^{2}$, Rogério Antônio Ribeiro \\ Rodrigues ${ }^{3}$, Elane Guerreiro Giese ${ }^{3}$, Daiene Costa do Carmo ${ }^{4}$, Juliana Teixeira Santos ${ }^{4}$ \& Ana Rita de Lima ${ }^{2}$
}

\begin{abstract}
Background: The Tayra (Eira barbara) is a mammal of the family Mustelidae with a significant presence in Latin America, it is considered an opportunist and extremely agile omnivorous. Some organs compose the digestive system and the stomach is a substantial organ for this system. The stomach have a small and a large curvature and the regions of the cardia, fundus, body and pylorus. Histologically, the stomach is made up of four layers or tunics that contributes in digestive functions. However, due the limited information available in the literature about morphophysiology of wildlife, this study aimed to clarify the morphology of Eira barbara stomach to understand your digestive system.

Materials, Methods \& Results: Three males and three females of Eira barbara species were studied (all young adults), all samples were originated of the Bauxite Mine area, in Paragominas, Pará state, Brazil provided of donation to Morphological Animal Research Laboratory (LaPMa) of the Universidade Federal Rural da Amazonia (UFRA), after death by trampling. The corpses were treated with aqueous $10 \%$ formaldehyde solution intramuscular injections, subcutaneous and intracavitary. After dissection, the collected material was processed following histologic standard protocols for the subsequent preparation of slides. The studied animals showed the stomach on the left antimere the abdominal cavity, with saccular format with the presence of large and small curvatures. The organ showed composite mucosa made with various gastric folds distributed in regions of the cardia, fundus and pylorus. A microscopic analysis of Eira barbara stomach revealed the presence of tunics or layers which gradually invaginate the lumen of the organ and underlying lamina propria was located to the prismatic epithelium and muscular mucosae and mucosa itself. In the region of the cardia, the muscle layer was deeply situated on the lamina propria, consisting of smooth muscle tissue with circular and longitudinal fibers. The submucosa consists of loose connective tissue; it is much thicker than the lamina propria and has many vessels. The first portion of the stomach showed long glands, while with short pits. In light microscopy, the fundic region revealed the presence of a highly pleated epithelium with elongated glands composed of clear and basally placed cells, with flattened nuclei. These cells are named mucous. Along the short region of the gastric pits, the presence of large cells was reported, pyramidal or rounded, central nucleus, called parietal. The pyloric region microscopy revealed the presence of short glands, similar to those previously described in the cardia region. The wide presence of goblet cells in the final portion of the pylorus indicated gradual transition between the regions of the stomach to the intestine, called duodenum-pylorus transition. The muscular layer showed thick muscle bundles just in circular direction, being responsible for the formation of the pyloric sphincter.

Discussion: The morphological analysis of the stomachs showed morphological and topographical similarities to the literature description for pets and wild mammals, however, were found in abundant quantities goblet cells in the transition duodenal pylorus. The goblet cells are located throughout the length of the small and large intestine and are responsible for the production and maintenance of the protective mucus synthesizing as glycoproteins known as mucins.
\end{abstract}

Keywords: Anatomy, digestive system, histology, Eira barbara, stomach.

${ }^{1}$ Graduação Medicina Veterinária, ${ }^{2}$ Laboratório de Pesquisa Morfológica Animal (LaPMA) \& ${ }^{3}$ Laboratório de Histologia e Embriologia Animal (LHEA), Universidade Federal Rural da Amazônia (UFRA), Belém, PA, Brazil. ${ }^{4}$ Mineração Paragominas S/A (MPSA) - Hydro Paragominas -Empresa Eco Florestal, Belém. CORRESPONDENCE: A.R. Lima [vetlima@ uol.com.br - Tel.: +55 (91) 988950233]. Instituto da Saúde e Produção Animal, UFRA. Av. Perimetral n. 2501. Bairro Terra Firme. CEP 66077-830 Belém, PA, Brazil. 


\section{INTRODUCTION}

The tayra (Eira barbara), is a mammal belonging to the Mustelidae family, weighing on average $4.5 \mathrm{~kg}$. It has round and small ears, and an elongated body and tail that can reach up to $1 \mathrm{~m}$ in its entirety $[21,25,27]$. It is predominantly found in tropical and subtropical regions [7]. E. barbara is an opportunistic omnivore, able to consume a variety of foods, including small fruits, carcasses, small vertebrates, insects and honey [3,10]. According some authors [14,15], the tayras are able to tolerate the proximity to human dwellings, in order to take advantage of food resources from these altered environments.

The stomach is a substantial organ for the digestive system, characterized as simple (glandular) or compound (glandular and non-glandular region). The stomach having a small and a large curvature and can be didactically split and consists of the regions of the cardia, fundus, body and pylorus [9].

Histologically, the stomach is made up of four layers or tunics. Is possible to identify the mucosa and submucosa layers, followed by muscular and serous layer, each respectively contributing in digestive functions. These tunics or layers vary little in their development, not only between species but also within different areas of the stomach [1].

Because of the literary shortage available to study wildlife morphophysiology, this study aimed to elucidate the morphology of the stomach of Eira barbara in order to broaden the understanding of the digestive system of the specimen in question.

\section{MATERIALS AND METHODS}

\section{Animals}

We studied three males and three females (all young adults) of wildlife Eira barbara from the area of Paragominas Bauxite Mine, Pará state, Brazil under the authorization of SEMA-PA under the numbers 455/2009 and 522/2009, donated to Animal Morphological Research Laboratory (LaPMa) of the Federal Rural University of Amazonia (UFRA) after death by trampling.

\section{Methodology}

The previously cryopreserved animals were thawed out in running water and thereafter fixation and preservation of the body was held, using $10 \%$ aqueous formaldehyde solution by intramuscular, subcutaneous and intracavitary applications, and then the specimens were kept submerged in the same solution in a suitable container for a minimum period of seven days. Finally, with the aid of basic materials, dissection was carried through the linea alba incision for the purpose of accessing the abdominal cavity and to enable withdrawal of the stomach for further preparation of histological slides. The measurement was performed with the aid of a digital caliper and tape measure, taking into consideration the lumen of the organ, thickness and length of their curvatures.

\section{Histological analysis}

The collected fragments were subjected to histological routine process of dehydration and paraffin embedding, subsequently making sections on LEICA 2165 microtome, with a thickness of $5 \mu \mathrm{m}$ and subsequently stained with hematoxylin-eosin (HE) [26]. The histological slides were examined and photographed with the help of LEICA E - 400 light microscope.

All nomenclature adopted was based on the Nomina Anatomica Veterinaria [16].

\section{RESULTS}

The stomach is a significant expansion of the digestive system of Eira barbara, on the level of the 6th to the 10th rib and which is closely located between the esophagus and the first third of the small intestine (duodenum).

The studied animals showed the stomach on the left antimere the abdominal cavity, with saccular format with the presence of large and small curvatures and connected on the cranial end to the abdominal esophagus and on the caudal end to the to the duodenum (Figure 1). The organ showed composite mucosa

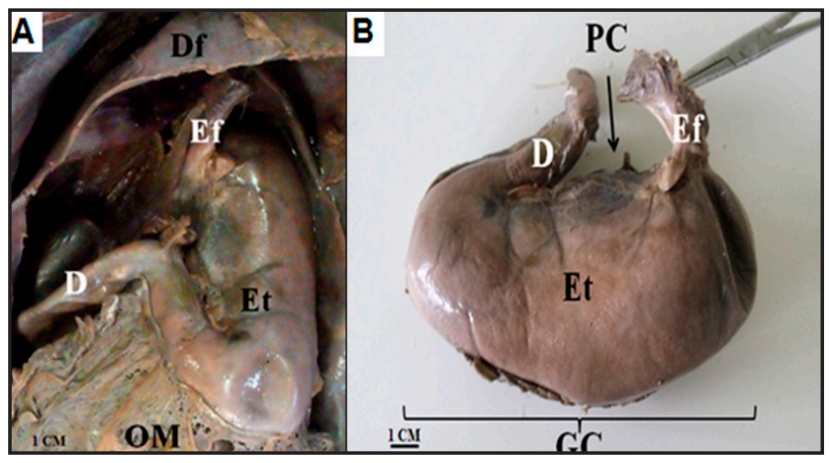

Figure 1. Photomacrographs of Eira barbara stomach. A- Stomach (Et) in situ located on left antimere. Observe the topographic relationship with the diaphragm (DF), esophagus (Ef), du-odenum (D) and omento (OM) joined the great curvature. B- Stomach (Et) ex situ being possible to identify the small curvature (PC) and the large curvature (GC), which is part of the esophagus (Ef) and duodenum (D). [Bar= $1 \mathrm{~cm}]$. 
made with various gastric folds distributed in regions of the cardia, fundus and pylorus (Figure 2A). Macroscopically, the pyloric region revealed more developed muscles and deeper rugae in relation to the others (Figure 2B).

The measurement of large and small curvature of the stomach of all Eira barbara specimens used in this study in in Table 1. Despite the striking difference between the measurements of the bodies of individuals, the ratio between the highest and lowest curves are roughly equivalent to 3.2 for males and 2.4 for females.

A microscopic analysis of Eira barbara stomach revealed the presence of tunics or layers which gradually invaginate the lumen of the organ and which

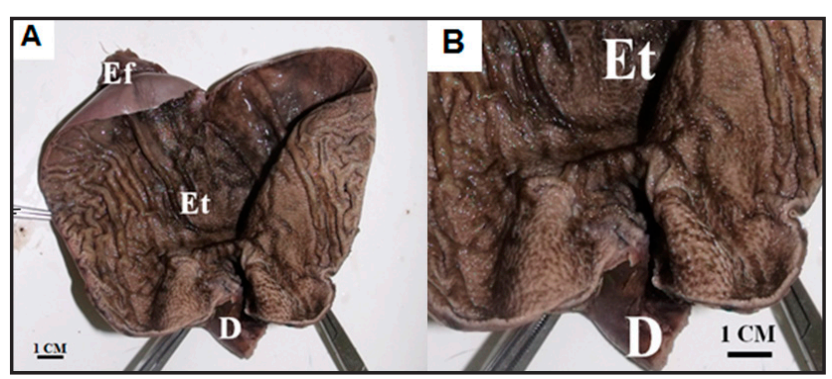

Figure 2. Photomacrographs of Eira barbara stomach. A- Observe the presence of various gastric folds diffusely distributed by the wall of the stomach (Et), part of the esophagus (Ef) and duodenum (D). B- Pyloric region of the stomach $(\mathrm{Et})$ and part of the duodenum (D). [Bar= $1 \mathrm{~cm}$ ].

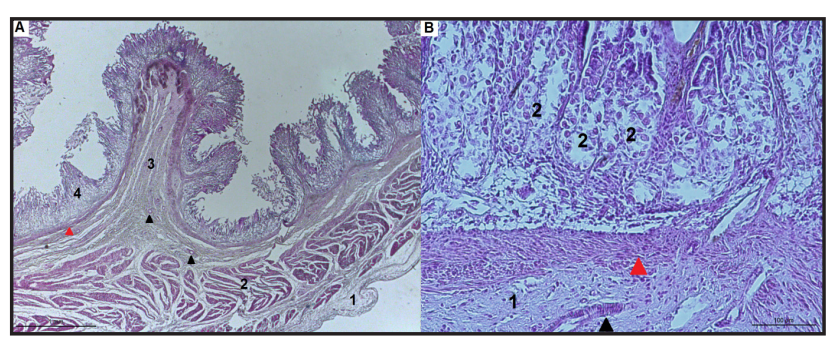

Figure 3. Photomicrographs of cardic region the stomach of Eira barbara. A- Tunica serosa (1), tunica muscular (2), tunica submucosa (3), tunica mucosa (4). Muscular Layer of mucosa (red arrow). Blood vessels (black arrows). H\&E. [Bar=1 mm]. B- Tunica submucosa (1), gastric intraretinal short (2), muscular layer of mucosa (red arrow), part of a blood vessel (black arrow). H\&E. [Bar= $100 \mu \mathrm{m}]$.

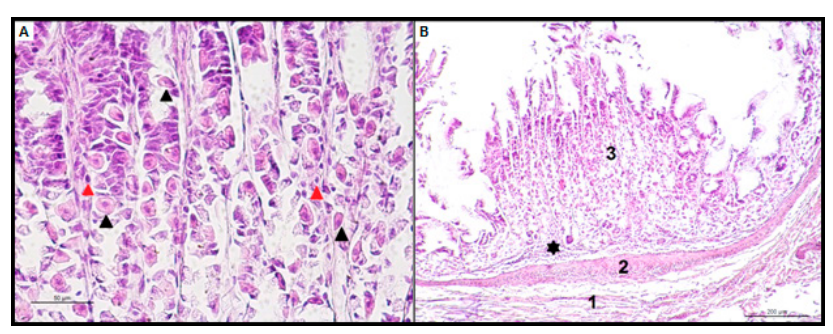

Figure 4. Photomicrographs from the fundus of the stomach of Eira barbara. A- Parietal cells (black arrows), mucous cells (red arrows). H\&E. [Bar=50 $\mu \mathrm{m}]$. B- Tunica submucosa (1), muscular layer of mucosa (2), epithelium highly creped of intraretinal gastric mucosa (3), basal lamina flat causing reduction of hyper cellularity (star). H\&E. [Bar $=200 \mu \mathrm{m}]$. are simultaneously present in the regions of the cardia, pylorus and fundus thereof. The underlying lamina propria was located to the prismatic epithelium and muscular mucosae and mucosa itself (Figures $3,4 \& 5$ ).

In the region of the cardia, the muscle layer was deeply situated on the lamina propria, consisting of smooth muscle tissue with circular and longitudinal fibers. These three layers together constitute the mucosal layer of the stomach. The submucosa consists of loose connective tissue; it is much thicker than the lamina propria and has many vessels. The first portion of the stomach showed long glands, while with short pits (Figure 3).

In light microscopy, the fundic region revealed the presence of a highly pleated epithelium with elongated glands composed of clear and basally placed cells, with flattened nuclei. These cells are named mucous and in general, are glycoconjugates producers. Along the short region of the gastric pits, the presence of large cells was reported, pyramidal or rounded, central nucleus, called parietal (Figure 4). The size of the elongated glands triggered the reduction of tissue present in the lamina propria, making it smaller compared to other regions (Figure 4B).

The pyloric region microscopy revealed the presence of short glands, similar to those previously described in the cardia region. The pits had become deeper, however. The wide presence of goblet cells in the final portion of the pylorus indicated gradual transition between the regions of the stomach to the intestine, called duodenum-pylorus transition. The muscular layer showed thick muscle bundles just in circular direction, being responsible for the formation of the pyloric sphincter (Figure 5).

\section{DISCUSSION}

Because of the scarcity of morphological studies of the digestive system of wildlife with emphasis on Mustelidae family species, like the tayra, advanced studies related to morphometric and morphologic aspects in this area are necessary, in order to support future research.

The morphology of the stomach is closely related to dietary habits of a particular specimen, causing the organ to be characterized as single or complex. This citation is justified due to the presence of macroscopic and microscopic structures inherent in the composition of the organs of the digestive tract, which are 


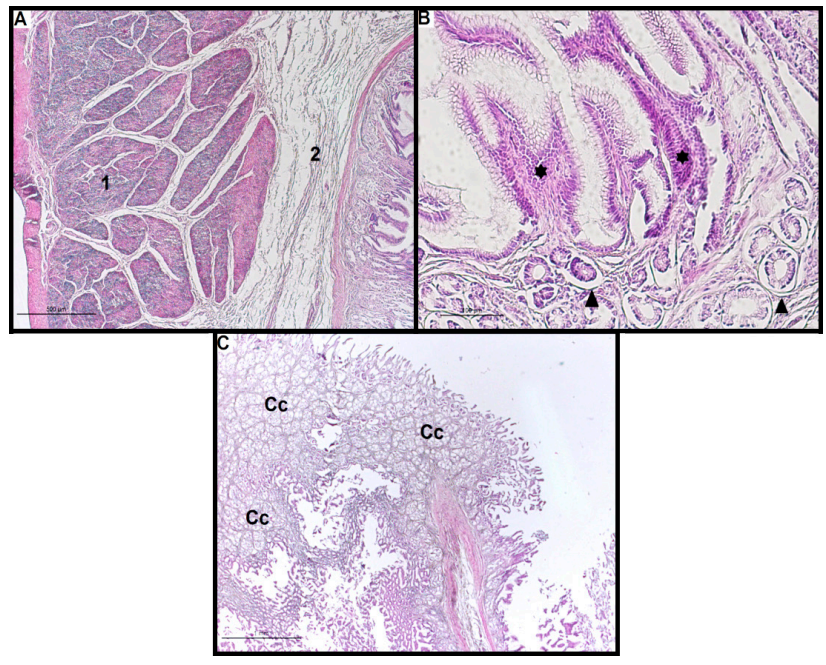

Figure 5. Photomicrographs of pyloric region of the stomach of Eira barbara. A- Muscular tunica containing only circular beams (1), tunica submucosa (2). H\&E. [Bar=500 $\mu \mathrm{m}]$. B- Gastric intraretinal deep (star), flattened glands and short (arrows). H\&E. [Bar= $100 \mu \mathrm{m}]$. C- High quantity of goblet cells indicating the transition pyloric-duodenal (Cc). H\&E. [Bar= $1 \mathrm{~mm}]$.

determined according to the nature of the food and how it will be subsequently ingested and processed [6]. Therefore, the digestive morphology has variable character, characteristics may vary even in animals belonging to the same class as evidenced [5], in which the stomachs of White-lipped peccary (Tayassu pecari) and Collared peccary (Tayassu tajacu), are divided into four chambers, while the tayra (Eira barbara), nine-banded armadillo (Dasypus novemcinctus) and the crab-eating fox (Cerdocyon thous) have only one chamber [20,28].

Macroscopically, in the stomachs of all analyzed animals was observed externally the presence of greater and lesser curvatures between the regions of the cardia and pylorus. The greater curvature is four times larger than the lesser, according to the proportion for domestic carnivores [13]. Thus, it was shown to be different in case of tayra specimens.

From the internal perspective, the organ has only one cavity, with gastric folds diffusely distributed throughout the cardia, fundus and pyloric regions, as observed in other mammals $[8,9,13]$. Similar to that described for Kerodon rupestris stomach [2] and the stomach of Tamandua tetradactyla [20]. In the regions of the body and fundus of the stomach, a higher amount of more strongly pronounced mucosal folds was observed, as also reported in a study of the stomach of the black-tufted marmoset (Callithrix penicillata) [23].

Aspects concerning the stomach biometrics matters because of veterinary clinical needs, especially when it makes use of image diagnose as a way to further examination, such as ultrasound or radiography. To facilitate the display of images in an ultrasound examination of uterus in pregnant bitches, about six hours of food fasting is required [17]. While for the realization of radiological examination in pregnant bitches, fasting for seven to eight hours is necessary [19].

Histologically, all regions of the stomach of the tayra were arranged in histological layers, a characteristic of a tubular organ, i.e for four tunics, which are, from the outside to the inside, serous tunica, muscular tunica, submucosa and tunica mucosa $[1,8,11,18,22]$.

The inner surface of the tayra stomach presented superficial epithelial invaginations toward the lamina propria, featuring micro depressions called gastric pits. According to some authors [1,12,18,22], these pits are observed in the entire stomach and basically have the same morphology as observed in this study. Still according to the authors, the stomach epithelium is also constant, consisting of prismatic mucous cells. However, the same cannot be said about the glands present in the areas of the cardia, fundus and pylorus regions.

According to authors [18,24], regions of the cardia and the pylorus arte similar for presenting deep gastric pits and short glands. On the other hand, the fundus region and body have short pits and long glands, as well as observed in this study. Similar results observed

Table 1. Measurements of greater and smaller curvatures values described in medium (X) in centimeters (cm), of the stomachs from Eira barbara.

\begin{tabular}{cccccccc} 
& Males & & Average & & Females & & Average $\begin{array}{c}\text { General } \\
\text { Average }\end{array}$ \\
\hline 1 & 2 & 3 & & 4 & 5 & 6 &
\end{tabular}

\begin{tabular}{llllllllll}
$\begin{array}{c}\text { Greater Cur- } \\
\text { vature }\end{array}$ & $23.7 \mathrm{~cm}$ & $33.3 \mathrm{~cm}$ & $26.3 \mathrm{~cm}$ & $27.7 \mathrm{~cm}$ & $17.2 \mathrm{~cm}$ & $16.3 \mathrm{~cm}$ & $14.8 \mathrm{~cm}$ & $16.1 \mathrm{~cm}$ & $21.9 \mathrm{~cm}$ \\
$\begin{array}{c}\text { Smaller Cur- } \\
\text { vature }\end{array}$ & $7.4 \mathrm{~cm}$ & $9.9 \mathrm{~cm}$ & $8.2 \mathrm{~cm}$ & $8.5 \mathrm{~cm}$ & $7.1 \mathrm{~cm}$ & $6.8 \mathrm{~cm}$ & $6.2 \mathrm{~cm}$ & $6.7 \mathrm{~cm}$ & $7.6 \mathrm{~cm}$ \\
\hline
\end{tabular}


in histological description of the stomach of anteater specimens (Tamandua tetradactyla) [20]. These same authors observed a thickening in the muscle of the pyloric region, as it was observed in this work, but they do not report the abundant presence of goblet cells in the final part of this region, which was found in the analysis of the stomach of the tayra.

The serosa was present in all portions. This layer was found consisting of loose connective tissue. However, it may also present adipose tissue or even a simple squamous epithelial tissue layer, as predicted by the literature $[1,12,18,22]$, which were not observed in this study.

The muscular layer of the mucosa of the studied specimens was easily detected because of its location and cellular typicality, which refer to other mammals with simple stomach [4]. Moreover, it was observed in its broad totality that the findings in this study did not diverge from those observed on most domestic animals $[1,12,18]$, particularly regarding the lining epithelium, organ stratification in layers or tunics and the presence of cellular and glandular constituents in each portion of the studied organ.

\section{CONCLUSION}

The morphology of the Eira barbara stomach has been proved similar topographically as described in the literature for other domestic and wild mammals that hold the stomach cavity classified as simple. However, the highlight was the epithelium in this final portion of the pylorus, which showed abundant amount of goblet cells in the pyloric-duodenal transition.

Declaration of interest. The authors report no conflicts of interest. The authors alone are responsible for the contents and writing of the paper.

\section{REFERENCES}

1 Banks J.W. 1992. Histologia Veterinária Aplicada. São Paulo: Manole, 629p.

2 Borsari F.N., Martins L. L., dos Reis A.C.G., da Cruz C., Oliveira M.F. \& Machado M.R.F. 2010. Análise macroscópica e microscópica do estômago do Mocó (Kerodon rupestris). Revista Pubvet. 4: 868.

3 Cabrera A. \& Yepes J. 1960. Mamíferos sudamericanos. Buenos Aires: Ediar, 187p.

4 Carvalho C.A., Fernandes K.M., da Matta S.L.P., Fonseca C.C., Pinto R. \& Oliveira L.L. 2011. Aspectos macroscópicos e histológicos da mucosa gástrica de ratos wistar e sua utilização em modelo de úlceras gástricas. Archives of Veterinary Science. 16: 44-53.

5 Cavalcante Filho M.F., Miglino M.A., Machado G.V., Bevilacqua E. \& Neves W.C. 1998. Estudo comparativo sobre suprimento arterial do estômago do queixada (Tayassu pecari) e do cateto (Tayassu tacaju) [Linnaeus, 1789]. Brazilian Journal of Veterinary Research and Animal Science. 35: 20-24.

6 Chaves P.T.C. \& Vazzoler G. 1984. Aspectos biológicos de peixes amazônicos III. Anatomia microscópica do esôfago, estômago e cecos pilóricos de Semaprochilodus insignis (Characiformes: Prochilodontidae). Acta Amazonica. 14: 343-353.

7 Cheida C.C., Nakano-Oliveira E., Fusco-Costa R., Rocha-Mendes F. \& Quadros J. 2006. Ordem Carnívora. In: Reis N.R, Peracchi A.L., Pedro W.A. \& Lima I.P. (Eds). Mamíferos do Brasil. Londrina: Universidade Estadual de Londrina, pp.231-275.

8 Didio L.J.A. 2002. Sistema digestório. In: Didio L.J.A. (Ed). Tratado de Anatomia Sistêmica Aplicada. São Paulo: Atheneu, pp.463-582.

9 Dyce K.M., Sack W.O. \& Wensing C.J.G. 2010. Tratado de Anatomia Veterinária. Rio de Janeiro: Elsevier, 872p.

10 Emmons L.H. \& Freer F. 1990. Neotropical rainforest mammals: a field guide. Illinois: University of Chicago Press, $281 p$.

11 Frappier B.L. 2006. Digestive system. In: Eurell J.A. \& Frappier B.L. (Eds). Dellmann's Textbook of Veterinary Histology. Ames: Wiley-Blackwell, pp.170-211.

12 George L.L., Alves C.E.R. \& Castro R.R.L. 1998. Histologia Comparada. São Paulo: Roca, 298p.

13 Getty R. 1986. Anatomia dos animais domésticos. Rio de Janeiro: Guanabara Koogan, 2048p.

14 Hall E.R. \& Dalquest W.W. 1963. The mammals of Veracruz. v.14. Museum of Natural History: University of Kansas Publication, pp.165-362.

15 Hershkovitz P. 1972. The recent mammals of the Neotropical region: a zoogeographical and ecological review. In: Keast A., Erk F. C. \& Glass B. (Eds). Evolution, mammals, and southern continents. Albany: State University of New York Press, pp.311-431. 
16 International Commiittee on Veterinary Gross Anatomical Nomenclature. 2017. Nomina Anatomica Veterinaria. 6th edn. Hannover: Editorial Committee, 178p.

17 Jarreta G.B. 2004. Ultra-sonografia do aparelho reprodutor feminino. In: Carvalho C.F. (Ed). Ultra-sonografia em pequenos animais. São Paulo: Roca, pp.181-206.

18 Junqueira L.C. \& Carneiro J. 2008. Histologia Básica. Rio de Janeiro: Guanabara Koogan, 542p.

19 Kustritz M.V.R. 2005. Pregnancy diagnosis and abnormalities of pregnancy in the dog. Theriogenology. 64: 755-765.

20 Pinheiro A.C.O., Lima A.R., Carvalho A.F., Pereira L.C. \&. Branco É. 2014. Aspectos morfológicos macro e microscópicos do estômago de tamanduá-mirim (Tamandua tetradactyla). Arquivo Brasileiro de Medicina Veterinária e Zootecnia. 66: 1089-1096.

21 Presley S.J. 2000. Eira barbara. Mammalian Species. 636: 1-6.

22 Samuelson D.A. 2007. Tratado de histologia veterinária. Rio de Janeiro: Elsevier, 544 p.

23 Silva L.C.S. 2012. Contribuição ao estudo do estômago do sagui-de-tufo-preto (Callithrix penicillata). 81f. Dissertação, Faculdade de Medicina Veterinária e Zootecnia, Universidade de São Paulo.

24 Stinson A.W. \& Calhoun M.L. 1982. Sistema Digestivo. In: Dellman H.D. \& Brown E.M. (Eds). Histologia Veterinária. Rio de Janeiro: Guanabara Koogan, pp.164-211.

25 Sunquist M.E., Sunquist F.C. \& Daneke D.E. 1989. Ecological separation in a Venezuelan llanos carnivore community. In: Redford K. \& Eisenberg J. (Eds). Advances in Neotropical Mammalogy. Gainesville: Sandhill Crane Press, pp.197-232.

26 Tolosa E.M.C., Rodrigues C.J., Behmer O.A. \& Freitas Neto A.G. 2003. Manual de técnicas para histologia normal e patológica. São Paulo: Manole, 341p.

27 Tortato F.R. \& Althoff S.L. 2007. Variações na coloração de iraras (Eira barbara Linnaeus, 1758 - Carnivora, Mustelidae) da Reserva Biológica Estadual do Sassafrás, Santa Catarina, sul do Brasil. Revista Biota Neotropica. 7: $365-367$.

28 Van Leeuwen P. 2002. Significance of combined nutritional and morphological precaecal parameters for feed evaluation in nonruminants. 153p. Thesis. Thesis of Wageningen University, Wageningen. 